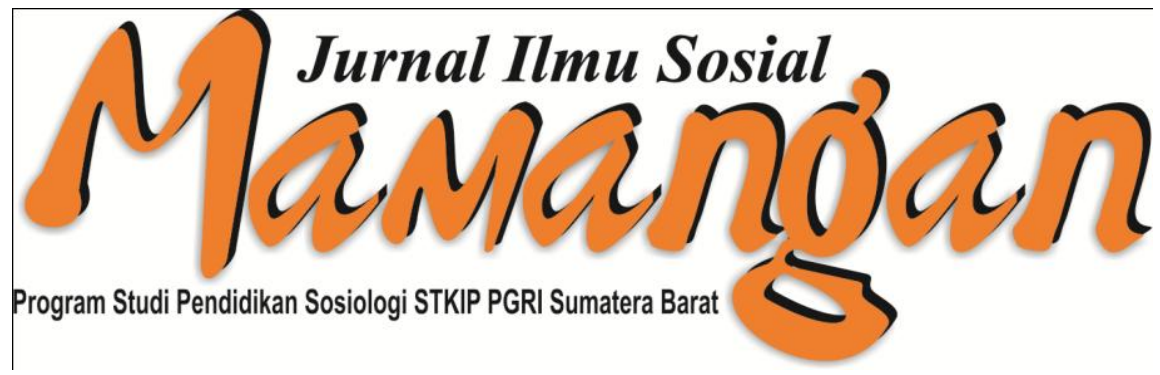

Jurnal Ilmu Sosial Mamangan

Volume 7, Number 2, July-December 2018

Social Rehabilitation Constraintsin Chidlren Facing The Laws Management Author : Prike Agusti Ningrum, Elfitra \& Bob Alfiandi

Source : Jurnal Ilmu Sosial Mamangan, Volume 7, Issue 2, July-Desember 2018

Published by : Laboratorium Pendidikan Sosiologi, STKIP PGRI Sumatera Barat

To Cite the Articel:

Ningrum, Prike Agusti, Elfitra \& Bob Alfiandi, 2018.Social Rehabilitation Constraints In Children Facing The Laws Management. Jurnal Ilmu Sosial Mamangan, Volume 7, Issue 2, July-December, 2018: 62-69.

Copyright (C) 2018, Jurnal Ilmu Sosial Mamangan ISSN : 2301-8496 (Print), ISSN : 2503-1570 (Online) 


\title{
SOCIAL REHABILITATION CONSTRAINTSIN CHILDREN FACING THE LAWS MANAGEMENT
}

\author{
$\mathbf{S}$ \\ Prike Agusti Ningrum ${ }^{1}$, Elfitra $^{2}, \&$ Bob Alfiandi ${ }^{3}$ \\ 1,2,\&3Magister Sosiologi, Universitas Andalas, Padang \\ Email: ${ }^{1}$ prikeningrum11@gmail.com, ${ }^{2}$ Elbaik069@gmail.com\& ${ }^{3}$ bobalfiandi@gmail.com
}

\begin{abstract}
Rehabilitation program for children facing laws (ABH) is a government effort to fulfill $\mathrm{ABH}$ basic right during their time in the social walfare institutions, such as Panti Sosial Asuhan Anak Bina Remaja (PSAABR). In the proess, there are constraints in organizing social reabiliation for $A B H$. The aim of this research is to find out the constraints facing PSAABR in organizing social rehabilitation for $\mathrm{ABH}$. The current research uses structuration theory pionerred by Anthony Giddens who focuses on the duality relationship between agents and structures. The research is conducted with double hermeneutic approach as one of the sub types in qualitative research. Data arecollected from participants observation and by interview. The research findings show that in social rehabilitation are there constraints facing PSAABR which occur due to the lack of human resources to handle $\mathrm{ABH}$, limited fund, limited facilities and the lack of competence of special mentor for ABH. Constraints which occur in $\mathrm{ABH}$ social rehabilitation process in PSAABR are structural.It means the constraints which occur are the consequence from structural factors causing ineffective ABH social rehabilitation process conducted by PSAABR management.
\end{abstract}

Keywords : Constraints, Children facing laws (ABH), Social Rehabilitation

\section{INTRODUCTION}

Children protection problems in Indonesia have been more difficult and complex over the years. One of the serious and urgent problems is children facing laws (ABH) management (R. Lestari, 2015). In handling $\mathrm{ABH}$, there must be persuasiveeducative approach and psychology approach, which means avoding punishment processes which merely put emphasise on punishing, degrading mentality, and discouraging $\mathrm{ABH}$ spirit as well as avoiding thestigmatization process which can possibly hinder children development process, children maturity and children independency in a positive meaning (Wibowo, 2018).
Based on the basic laws (UUD) Number 11, 2012 about criminal justice system for children (SPPA), that ABH definition refers to those children who become criminal suspect, criminal victim and criminal witness. Meanwhile, based on age, $\mathrm{ABH}$ is the children aged between 12-17 years old who allegedly commit crimes. According to the basic law (UUD), $\mathrm{ABH}$, starting from investigation process until judicial decision, should be rehabilitated in the social walfare institutions for $\mathrm{ABH}$.

$\mathrm{ABH}$, according to the basic laws (UU) on the criminal justice system for children(SPPA), should be rehabilitated to return or recover their physical and psychological condition resulted from the 
problems they face. Social rehabilitation is the recreating and developing process to allow someone do their social functions properly in society. So, it is ultimately essential to conduct social rehabilitation in attempt to maintain ABH. Since 2015, ABH in west Sumatra has been undergoing social rehabilitation in Panti Sosial Asuhan Anak Bina Remaja Budi Utama Lubuk Alung. It, furthermore, can be abbreviated PSSABR. Based on the basic laws on social issues number $44 / \mathrm{Huk} / 2015$, the PSSAABR is the social rehabilitation place for $\mathrm{ABH}$.

$\mathrm{ABH}$ cases in Indonesia have increased in the last five years. Based on data, in June 2014 there were 2.060 children (1.891 males and 169 females) detained in various institutions across Indonesia and are still in judicary process. The number of children convicts in Indonesia reaches 3.379 children (3.095 males and 284 females) and has been in the final judiciary process. This number has increased compared to the number in $2011 . \quad$ Children protection commissionerreports that there are 1.851 complaints on the children facing the laws (theft, violence, rape, drug abuse, gambling and persecution) (Hizba et al., 2014)

The data published by the Indonesia children protection commissioner (KPAI) show the number of children convicts across Indonesia on March - July 2016; 17.220 children, 16.759 children, 16.096 children, 15.025 children and 14.584 childrenrespectively. The number of children convicts every month in 2016 decreased, but still categorized high. The Indonesian children protection commissioner (KPAI) also published the data of number of the children facing the laws which is still high over the years. In 2011 there were 695 children, raising to 1.413 children in 2012. In 2013 it raised to 1.428 children and lastly in 2014 it raised highly to 2.208 children. In 2015 it declined to 1.221 children and in 2016 until July 2017 there were 167 children (Amrullah, 2017).

The researches on social rehabilitation process occur in various rehabilitationinstitutions. several hampering factors in rehabilitating sexual children convicts are; children character, no intention to join counselling, lack of psychiatrist, and lack of religious supervisor (Romi, Yuliatin, 2018). One of hampering factorsInthe social rehabilitation process is the limited function and role of social officers especially after rehabilitation (Arifin, 2016). The role of social officers in developing teenagers' behaviour must be active as facilitator, broker, mediator, defender and protector, as well as friend second parent. This maintenance can also allow to resolvs teenagers' issues and can affect children behaviour. In the maintenance, children get access to vocational workshop, physical and spiritual supervision. Which is beneficial for their lives (Yani \& Jas, n.d.). the maintenance conducted is not careless but has procedurs and mechanism which have been set up properly based on rehabilitation client needs (Ilyas, 2016). Meanwhile, one of the other factors which hinders the social rehabilitation process is people with social welfare issues, such as people with disability (Saputro, 2017) .

From available literatures, the researches about social rehabilitation for $\mathrm{ABH}$ do not find out constraints in the social rehabilitation specifically for $\mathrm{ABH}$ in the social welfare institution (LPKS). Hence, the current researcher is interested in examining structural constraints related to the social rehabilitation for $\mathrm{ABH}$ in LPKS, which is PSSAABR.

The initial purpose of the basic laws (UU) on the criminal justice system for children (SPPA) is to make sure the effective implementation of the social rehabilitation for $\mathrm{ABH}$. However, the realization which occurs in PSAABR doesn't show any effectiveness in terms of the social rehabilitation process. It is assumed that this ineffectiveness happens due to structural constraints in the social rehabilitation process for $\mathrm{ABH}$.

Based on the problems stated above, the current research is aimed to know the constraints in the social rehabilitation process for ABH in PSSABR. The research will theoretically contribute for other researchers to complete their study which will develop scientific knowledge related to the constraints in social rehabilitation process for $\mathrm{ABH}$ in PSAABR. Practically the results of this study can contribute at providing suggestions for people in charge to evaluate social rehabilitation program for $\mathrm{ABH}$ not only from management aspects but also 
institutions to make the application better in the future.

\section{RESEARCH METHODS}

This research was conducted in social welfare institution of Anak Bina Remaja Budi Utama (PSSABR) Lubuk Alung for 6 months since January to June 2017. Based on the problems and aims which have been described earlier, this research applied qualitative method with double hermeneutic by Anthony Giddens with descriptive approach.Double hermeneutic by Anthony Giddens is one of the sub types in qualitative research. In this kind of research, the researcher not only conducts research but also he/she becomes part of the research context to enable him/her to interprate the meaning of treatment done from observed object.

Data were collected from interview protocol to participants and data collected from related institutions. Data collection was done with a technique where the researcher became part of management officers in PSAABR. It allows them observe participants directly and see the real constraints faced in social rehabilitation for $A B H$ in PSAABR. Interview was done with PSAABR management who understands about the constraints in ABH management in PSAABR.

Data analysis applied in the current research is the double hermeneutic by Giddens in structuration theory. Data analysis was done from the beginning of data collection because researcher took a part and stay in PSAABR, therefore, during data collection, the researcher has understood deeply the meaning of every occurrence in the process.The researcher got the data based on double interpretations, which possibly happen by taking a part in the research context and received the data from participants. The research was stopped when the researcher got the raw data about the constraints in social rehabilitation for $\mathrm{ABH}$. To prove the righteousness of the data, data triangulation was done to $\mathrm{ABH}$ which finally showed the similarity of the data collected from $\mathrm{ABH}$ with the data stated bt PSAABR.

Data presentation process was done after the data collected and categorized in the narration form according to research problems. Next step was data interpretation based on what participants interpreted on the constraints in social rehabilitation process for $\mathrm{ABH}$ in PSAABR.

\section{RESULT AND DISCUSSION}

Social rehabilitation for $\mathrm{ABH}$ according to the basic laws (UUD) on the criminal justice system for children (SPPA) can be defined as a recreation and development process to allow somebody do the social function properly in society. This process acts as a diversion process for legal process, which is beung detained in the social welfare institutions (LPKS) as a place for ABH right fulfilment as a child. LPKS in this case is PSAABR which is set to have the homey atmosphere for $\mathrm{ABH}$. The $\mathrm{ABH}$ rehabilitation process is deference to children right to grow and get protection, right to get physical needs, educations, and recreations.

The research result describes that PSAABR management face problems in $\mathrm{ABH}$ rehabilitation. Based on participants observation and interview protocol, here is the results:

The Lack of Human Resource

Human resource is one of the essential and inevitable factors from an organisation, both institutions and companies. Human resource is also a key which determines the companies' development. Human resource is the people who are hired in an organisation or company as a motor, thinker and planner to achieve the companies' or organisations' goals. Generally, human resource is defined as individuals who work as the motor for an organisation, both institutions and companies, and are functioned as an asset which should be well trained and developed. Based on the basic laws (UUD) of SPPA and based on job desc listed on the standard operating procedure (SOP), PSAABR has 10 ABH mentors, 5 social workers, 2 caregivers, 2 skill supervisors and 1 religion supervisor. However, in fact there are just $4 \mathrm{ABH}$ mentors, 2 social workers, 1 caregiver and 1 religion supervisor, whom have something else to focus on other than $\mathrm{ABH}$.

Based on the findings explained above related to human resource, it can be stated that the most basic problem faced by PSAABR is the lack of human resource. Who can boost the success of the rehabilitation management program for ABH in PSAABR. Management is not sure about the rehabilitation process if it 
is only supported by limited manager and doesn't focus only on $\mathrm{ABH}$.

Adequate number of human resources can empower the PSAABR management in conducting $\mathrm{ABH}$ social rehabilitation. With the adequate number of resources, it is hoped that the task division for $\mathrm{ABH}$ mentors can be done properly. However, in ABH social rehabilitation, the number of human resources is not adequate. It can be seen from the number of $\mathrm{ABH}$ pertners, which is 4 people. skill supervisor is unavailable. There is only 1 caregiver, which doesn't fulfil the operasional standard requiring 10 mentors, 5 social workers, 2 caregivers, 2 skill supervisors and 1 religion supervisor. This fact shows that structure hinder agent in conducting $\mathrm{ABH}$ social rehabilitation.

The Lack of Fund For Children Facing The Laws (ABH)

Beside the lack of human resource, $\mathrm{ABH}$ management must be supported by sufficient budgetary fund. However, in fact the PSAABR limits the budgetary fund for $\mathrm{ABH}$. The available budgetary funds just focus on the primer PSAABR programs, for foster children and skills developments. Based on the basic laws about funds on the operasional standard, it is stated that there must be a budgetary funds for ABH needs every month.

Based on findings related to budgetary funds for $\mathrm{ABH}$, it can be stated that budgetary funds problem has become the most important problem to be considered to boost the success of rehabilitation program for $\mathrm{ABH}$. The program will not possibly be successfully without funds. The available funds are just for foster children program and skills development. Therefore, they are not aimed for $\mathrm{ABH}$ needs.

Adequate budgetary funds can empower the manager to conduct social rehabilitation for $\mathrm{ABH}$, in which with the adequate budgetary funds, the needs of $\mathrm{ABH}$ will be fulfilled. However, in fact, budgetary funds for $\mathrm{ABH}$ are very limited. It shows structure hinders agent in conducting sosial rehabilitation for $\mathrm{ABH}$.

Inadequate Infrastructures

Infrastructure is anything which acts as primary support of any process (business, construction and project). Meanwhile, according to Bahasa Indonesia dictionary, infrastructure is anything which can be utilized as a tool in achieving particular goals and aims.

Infrastructures in PSAABR for social rehabilitation process support are listed in the standard operating procedure. There must be activities to develop children skills. hence the availability of building for the activity is the most essential thing. There must be buildings for sport activities as well, such as field and exercise equipments. However, in reality, these infrastructures are available just for other purposes. The buildings and sport equipments are inadequate and are not allocated for $\mathrm{ABH}$. There is only one building for non $\mathrm{ABH}$.

Beside that, the next constraint is related to inadequate infrastructures for skill development. The absent of equipment utilized for skill development is also a problem for $\mathrm{ABH}$. There is only one activity which $\mathrm{ABH}$ and other children can do, which is soccer. Nevertheless, all kinds of infrastructures should be provided to ensure all $\mathrm{ABH}$ avoid doing something forbidden due to much time they spend without beneficial activities. The infrastructures for $\mathrm{ABH}$ are limited and there is available infrastructure only for foster children. The management of infrastructures between these different purposes should be differentiated. $\mathrm{ABH}$ usually play soccer with their mates in afternoon because it is the only activity they do in free time.

Based on the finding described above, it can be concluded that ABH in PSAABR is in need of adequate infrastructures. The infrastructures provided for $\mathrm{ABH}$, in fact, is equated with foster children and skill development purpose. There is only soccer activity with small soccer field in front yard. With that condition, PSAABR managers feel that it is very important to complete the available infrastructures to allow $\mathrm{ABH}$ have various activities to spend their free times out of their room.

To examine the data correctness, data triangulation was done to $\mathrm{ABH}$ who claimed that $\mathrm{ABH}$ in PSAABR seldom join skill development activity and sport activity. It is because all activities for $\mathrm{ABH}$ are not the focused activity. It shows similar result with what PSAABR manager stated. It can be concluded that the main constraint in social rehabilitation for $\mathrm{ABH}$ relates to the infrastructures' problems, which is 
inadequate infrastructures availability. Ideally, $\mathrm{ABH}$ must do skill development activities and sport activities based on standard operating procedure.

Adequate infrastructures can empower the manager in conducting social rehabilitation for $\mathrm{ABH}$. With the adequate infrastructures, all activities for $\mathrm{ABH}$ can possibly be done. But, in reality, the infrastructures are limited. It can be seen from the absent of sport equipments as well as the activities center. It shows structure hinders agent in conductinf social rehaibilitation for $\mathrm{ABH}$.

The Lack of Understanding About Social Rehabilitation For ABH.

Based on the basic laws (UU) article 1 paragraph 14 and 15 which states that PSAABR manager, especially social welfare worker, $\mathrm{ABH}$ must have competence and knowledge related to social rehabilitation for $\mathrm{ABH}$ in social welfare institutions. ideally, based on standard operating procedure, every $\mathrm{ABH}$ escort should be provided trainings at least once in a year. It is hoped that the trainings can develop understanding about $\mathrm{ABH}$ mentoring in conducting social rehabilitation for $\mathrm{ABH}$. But, in reality, the $\mathrm{ABH}$ mentors, such as caregivers and religion supervisors, never get any kind of training. The people who get trainings this far are stakeholder and social worker. Knowledge about social rehabilitation for $\mathrm{ABH}$ must be provided in order to make sure the implementation of social rehabilitation for $\mathrm{ABH}$.

Based on finding related to the understanding in $\mathrm{ABH}$ management, it can be concluded that one thing to support the implementation of social rehabilitation social is the awareness of social rehabilitation. It will ensure the process run more intensively. It will aso ensure the trainings go to the right place, which is the managers of PSAABR. They are the people who must be provided the knowledge about rehabilitation process.

Trainings on social rehabilitation for $\mathrm{ABH}$ are conducted to develop ABH mentors' understanding and empower managers and mantors. However in fact, the trainings are only provided for managers with civil servant (PNS) status and social workers. It shows that structure hinder agent in conducting social rehabilitation for $\mathrm{ABH}$.
Based on research result described above, there are several discussions as outlained below:

This research applies structuration theory by Giddens with integrative paradigm. The assumptions form the theory are:

1. Connection between structure and agent has duality character. It means there is an interplay process. It happens on the individuals. Hence it creates a structure. On a structure there is rule and resource. 2. Structure, beside having constraining character, also has a character to give chance for social treatment out of existing structure, which at the end become a reality.

Picture 1 below explains connection between theory and conducted research:

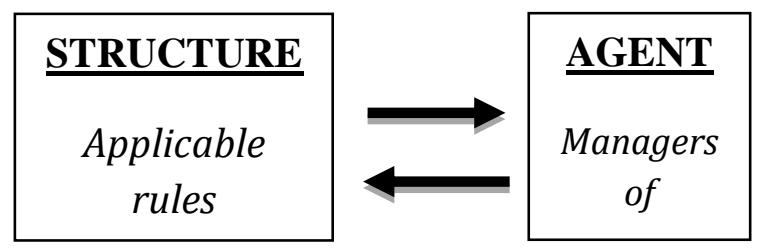

Picture1. CHART OF STRUCTURE AND AGENT IN THE RESEARCH

In structuration theory by Anthony Giddens there is dual connection between agent and structure. In this research, agent is the manager of PSAABR, who manage PSAABR and $A B H$ mentor. Structure is the rules in $\mathrm{ABH}$ sosial rehabilitation, which means there is dual connection between the manager of PSAABR with structure. Structure is constraining, but according to Giddens it gives a chance social action outside the structure to happen, which at the end becomes a realty.

Based on the explained theory about structure, it has two characters, constraining and enabling other actions to happen. Basically, structure factors can allow the agent to conduct social rehabilitation for $\mathrm{ABH}$. With good structure and adequate condition, it will support agent to conduct the social rehabilitation in daily basis. However, in fact there are so many weaknesses of structure in the field, lack of human resource, budgetary funds and knowledge about the social rehabilitation, and Inadequate infrastructures. It shows structrure hinder agent in conducting social rehabilitation.

The theory supporting this research should be seen from 2 sides: PSAABR 
manager, consisting of management and $\mathrm{ABH}$ mentor as the agent, and rules in in social rehabilitation for $\mathrm{ABH}$ as the structure. In order to handle problems in the ABH social rehabilitation, it is not only the agent's skills which need to be focused on but also the rules in the $\mathrm{ABH}$ social rehabilitation which has something to do with resource in PSAABR.

From current literature, researches on $\mathrm{ABH}$ social rehabilitation do not provide problems/constraints in $\mathrm{ABH}$ social rehabilitation in social welfare institution for $\mathrm{ABH}$. Research on social rehabilitation is conducted based on program which has been determined by social department to receiver of the rehabilitation, like bottow up and top down system done in social welfare institution in Nganjuk (Wajdi, 2017). UPTD PKS Insan Berguna provides service and social rehabilitation for $\mathrm{ABH}$, provides law protection and advocacy service, and prepare $\mathrm{ABH}$ to return to society (Seprilya, 2018). One of the institutions which accounts for troubled children, where social workers get involved, is Petirahan Anaksocial home. It is a social home which is obliged to give guidance and service to children who are troubled with study and have social problems to develop and heal their potency and capacity properly to engange in education (Puteri et al., 2016).The problem which usually occur when mentoring naughty children comes from 3M (Man, Management and Money). Man refers to the lack of human resource in mentoring clients and the solution is not found yet. Management refers to the leadership in which the solution has not been found yet. Money refers to the lack of budgetary fund, but it can be handled with independent activities done by social workers. (Ilyas, 2016). The problem faced by mentors when accepting the troubled children is when the parents give much money to the children. It is possible for the children to do something wrong with the money they get, purcashing glue to substitute drug.

The children will pass three stages in society, preparatory stage, play stage and game stage which show that the children undergo social experience and build understanding about themselves and their world (Diyah \& Ali, 2016). Parents' support is extremely essential for troubled children as well as religion guidance to allow them to heal and return to their roles in society (Arifin, 2016). The balance between knowledge they get from school and religion understanding from the institution is hoped to create a generation which has good knowledge and moral in doing their roles in society (Setiyawati, 2016).

Family interaction has a big role in triggering children' behaviour to be bad children and face the laws (Hizba et al,. 2014). The stages of social rehabilitation for ABH consist of three approaches. First approach, disclosure and problem solving, plan drafting for problem solving, implementation of problem solving, evaluation, termination, and reference as well as guidance and further guidance (Astuti, 2017). Social workers' role in $A B H$ management is as parole and probasi; Plan, implement and supervise $\mathrm{ABH}$ rehabilitation program: and manager in $\mathrm{ABH}$ rehabilitation institution (Hizba et al, 2014). The supervision given can be mentoring in psychology, religion, education as well as skills development. This supervision also refers to one of country's responsibility in maintaining, protecting and ensuring children right (Oemy, 2016). Social workers have program, which is assessment in the form of initial interview to find out victim case and educational background, if $\mathrm{ABH}$ doesn't go to school then they will get special education for skill development. (Mahfiyah et al., 2018).

The implementation of $\mathrm{ABH}$ protection and rehabilitation program faces problem and support: supporting factor is communication and socialization which create awareness and knowledge among the people, disposition with children and bureaucracy oriented, and constraining factor is human resource which is still lack of professional workers (P. Lestari, 2017)

It is different with children with drug abuse problem. When they pass rehabilitation period, they have right to undergo social rehabilitation and special program before returning to society based on the constitution regulation. It is hoped to bring benefit for the children and the society. Medical rehabilitation infrastructures for narcotic convicts are hoped to establish cooporation with social homes owned by government or people, and with social homes 
provided by people which give service after treatment (Sembiring et al., 2017)

And next, the constrains faced in rehabilitation right fulfilment for drug convicts are laws factor, authorities factor, infrastructures factor and environment factors. The effort done is coordination among institutions, and authorities in enforcing laws and supervising children convicts (Rasyid et al., 2017)

Based on relevant literature review which is more specific with this research, something which is different is on the factors discussed in social rehabilitation process. This research focuses on the structural constraints in PSAABR faced by management in $\mathrm{ABH}$ social rehabilitation process.

\section{CONCLUSION}

The constraints which happen in $\mathrm{ABH}$ social rehabilitation process in PSAABR are structural constraints. Structural here means the constraints which happen because of structure factors making the rehabilitation process ineffective. The constraints are lack of human resource, budgetary fund, inadequate infrastructures and lack of understanding about $\mathrm{ABH}$ management. All of these constraints make the process become ineffective.

If reviewed with structuration theory by Giddens, basically structure factors are the main problems which can possibly empower management in conducting social rehabilitation for $\mathrm{ABH}$. With good and adequate structure condition, it is hoped to support the process of $\mathrm{ABH}$ social rehabilitation on daily basis. However, in fact there are many structure constraints/problems, such as lack of human resource, budgetary funds, inadequate infrastructures and lack of understanding on $\mathrm{ABH}$ management method. It shows that structural factors hinder agents in ABH social rehabilitation.

For the next researchers who plan to conduct research with the same title, it is suggested to review on "ABH social interaction with other children under jurisdiction in PSAABR". Based on observation and interview results in the field, there are several problems/constraints faced by PSAABR related to the existence of $\mathrm{ABH}$ who live alongside the other children under jurisdiction, such as foster children in PSAABR. So, ABH will often interact with the other children in PSAABR who are not part of $\mathrm{ABH}$. It is worried that these children will imitate or do the same behaviour similar to $\mathrm{ABH}$.

\section{REFERENCES}

Amrullah, M. R. (2017). Peran perlindungan perempuan dan anak (ppa) dalam penanganan anak berkasus hukum di polres banyumas.

Arifin, B. A. (2016). Rehabilitasi Sosial Korban Napza Di Panti Sosial Marsudi Putra Toddopuli Kecamatan Biringkanaya Kota Makassar.

Astuti, S. P. (2017). Analisis Program Pendampingan Anak Berhadapan dengan Hukum Di Panti Sosial Marsudi Putra Antasena Magelang. 1(1), 11881197. https://doi.org/10.1111/j.14697610.2010.02280.x

Diyah, N. C. M., \& Ali, I. (2016). Kekerasan Dalam Pendidikan (Studi Fenomenologi Perilaku Kekerasan di Panti Rehabilitasi Sosial Anak). Jurnal Kekerasan Dalam Pendidikan, 4, 1-12.

Hizba, F., Suharto, A., Wibhawa, B., \& Hidayat, E. N. (2014). Interaksi Didalam Keluarga Dengan Anak Berhadapan Dengan Hukum di Panti Sosial Masurdi Putra Bambu Apus Jakarta. Share Social Work Jurnal, 5, 35-45.

Ilyas, M. B. (2016). Pembinaan Anak Nakal di Unit Pelaksana Teknis Rehabilitasi Sosial Anak Nakal Surabaya. Kajian Moral Dan Kewarganegaraan, 03, 18401854.

Lestari, P. (2017). Implementasi Program Perlindungan Dan Rehabilitasi Sosial Anak Berhadapan Dengan Hukum Berbasis Masyarakat (Prsabhbm) (Studi Komparatif Pada Pokja Sanggar Pengayoman Di Kelurahan Tonggalan , Kecamatan Klaten Tengah Dan Pokja Ceria Di Desa Sumber, Kecamat. Journal of Personality and Social Psychology, 1(1), 1188-1197. https://doi.org/10.1111/j.14697610.2010.02280.x

Lestari, R. (2015). Implementasi Konvensi Internasional Tentang Hak Anak (Convention on The Rights of The Child) 
Di Indonesia ( Studi kasus : Pelanggaran Terhadap Hak Anak di Provinsi Kepulauan riau 2010-2015. JOM FISIP Vol.4 No. 2 -Oktober 2017, 4(2).

Mahfiyah, S., Rohma, N., \& Muis, T. (2018). Studi Tentang Penanganan Penanganan Kasus-Kasus Anak Kriminal Di Yayasan Rumah Aman Sumur Nganjuk.

Oemy, Y. A. (2018). Pelaksanaan Pembinaan Anak Yang Berkonflik Dengan Hukum Oleh Lembaga Penyelenggara Kesejahteraan Sosial Panti Sosial Asuh Anak Bina Remaja (LPKS PSAABR) Budi Utama, Lubuk Alung.

Puteri, A. E., Mulyana, N., \& Raharjo, S. T. (2016). Peran Pekerja Sosial Dalam Proses Rehabilitasi Anak Bermasalah di Panti Sosial Petirahan Anak ( PSPA) satria. Prosiding KS: RISET \& PKM, 3, 254-259.

Rasyid, A., Diana, F., \& Nur, M. (2017). Pemenuhan Hak Rehabilitasi Narapidana Anak Dalam Kasus Narkoba Di Aceh (Studi Kasus Pada Cabang Rumah Tahanan Negara Lhoknga). Law Journal, 1(2), 37-52.

https://doi.org/10.1080/01596300903 037069

Romi, Yuliatin, M. (2018). Upaya Rehabilitasi Terhadap Anak Pelaku Kekerasan Seksual Di Panti Sosial Marsudi Putra Paramita Mataram. Juridiksiam Jurnal, (1), 1-10.

Saputro, M. B. (2017). Peran balai besar rehabilitasi sosial bina daksa prof. Dr. Soeharso surakarta dalam upaya pemenuhan hak bagi penyandang disabilitas fisik pada proses rehabilitasi. 1(1), 1188-1197. https://doi.org/10.1111/j.14697610.2010.02280.x

Sembiring, J., Mulyadi, M., Marlina, \& Ihkhsan, E. (2017). Pemberian Rehabilitasi Terhadap Anak Pelaku Tindak Pidana Narkotika (Studi Kasus Tiga Putusan Pengadilan). USU Law Journal, 5(1), 95106.

Seprilya, I. (2018). Peran Dinas Sosial Dalam Penanganan Anak Berhadapan Dengan Hukum Melalui Unit Pelaksana Teknis Dinas Penyelengara An Kesejahteraan Sosial Insan Berguna.

Setiyawati, E. (2016). Pelayanan Sosial Di Bidang Pendidikanpada Faith Based Organization ( Studi Di Rumah Yatim At-
Tamim Kecamatan Cileunyi Kabupaten Bandung ). Share Social Work Jurnal, 5. Wajdi, M. B. N. (2017). Rehabilitasi Anak Berhadapan Dengan Hukum Dalam Perspektif Agama (Studi Kasus Metode Pengembangan Mental Spiritual Anak Lembaga Penyelenggaraan Kesejahteraan Sosial Anak Berhadapan Dengan Hukum (LPKS ABH) di Nganjuk. JURNAL LENTERA: Kajian Keagamaan, Keilmuan Dan Teknologi, 3(1), 188-200. Wibowo, A. (2018). Hukum pada Lembaga Pemasyarakat Orang Dewasa : Suatu Kajian Literatur. Ilmu Kesejahteraan Sosial, 159-181.

Yani, F., \& Jas, J. (n.d.). The Role Of Social Workers In Adolescent Learning In Social Hospital Bina Teen ( Psbr) Rumbai Pekanbaru Peran Pekerja Sosial Dalam Pembinaan Remaja Di Panti Sosial Bina Remaja ( PSBR ) Rumbai Pekanbaru. 5, 1-13. 